\title{
The Assessement of the Compositional and Microbiological Parameters of some Meat Products Manufactured in a Small Processing Unit
}

\author{
S. VIDA ${ }^{1}$, S. D. DAN ${ }^{1 *}$, M. MIHAIU ${ }^{1}$, Oana REGET ${ }^{1}$, I. V. CORDIŞ ${ }^{1}$, D. CORDEA ${ }^{1}$, Alexandra TĂBĂRAN ${ }^{1}$ \\ ${ }^{1}$ Department of Animal Production and Food Safety, Univesity of Agricultural Sciences and Veterinary \\ Medicine, Faculty of Veterinary Medicine, 3-5 Mănăştur Street, 400372, Cluj Napoca, Romania. \\ Corresponding author: sorindan@usamvcluj.ro \\ Bulletin UASVM Veterinary Medicine 72(1) / 2015, \\ Print ISSN 1843-5270; Electronic ISSN 1843-5378 \\ DOI:10.15835/buasvmcn-vm: 11120
}

\begin{abstract}
The hygienic quality of meat products can be substantially improved by respecting strictly the rules of Good Hygienic Practice (GHP) and the rules of Good Manufacturing Practice (GMP) along the entire food chain.The aim of this study was to evaluate the compositional and hygienic parameters of meat and meat products processed in a small scale processing unit, and to assess the microbial risk represented by the total plate count, E. coli and Salmonella spp. The research materials were collected from a small scale meat processing unit located in Maramures County during January-Mai 2014, 15 samples from each of the following types of products: fresh pork meat, smoked salami, cold smoked sausages, raw dry smoked specialities. In order to assess the quality of meat products, all the samples were processed through standardized protocols. Also, the results were statistically analysed using ANOVA monofactorial analysis. Some compositional parameters are accordance with the standards (salt, nitrates and total ammonia content). For the previously mentioned category of products the following compositional parameters were not in accordance with the maximum and minimum limits of the standards: proteins, fatness and humidity. The main nonconformities identified regarding compositional parameters in case of smoked salami were the lower values for protein content and the higher values in case of fat. Regarding the fresh sausages nonconformities they were represented mainly by the increased moisture and fat content. In case of raw meat products, the identified nonconformities were represented by the low protein and high fat and moisture content. The microbiological risk parameters represented by E. coli and Salmonella was low in all meat products.
\end{abstract}

Keywords: compositional parameters, hygienic quality, meat products, microbiological risk.

\section{INTRODUCTION}

Meat and meat products have won a significant role in human diet due to their higher nutritional qualities, which is why a special attention should be given to the veterinary hygiene rules needed in the products processing in order to ensure reduced microbial load as according to standards and current legislation (Bărzoi et Apostu, 2002). The nutritional value of animal products is a reality that can not be questioned, but equally true is the fact that these products can become unfit for consumption if a contamination with pathogens occurs (Rotaru et al.; Mihaiu, 2004). Meat and meat products, through their chemical composition, are more liable to bacterial contamination if not complied with the rules and hygiene measures throughout the process flow, thus representing an important source of food poisoning outbreak (Apostu et Stănescu, 2010). Primary production, processing and marketing of food of animal origin with lower risk conditions, is a major priority for the European Food Safety Authority (Mihaiu et al., 2011; Mihaiu et al., 2014). Hygienic quality of meat products can be substantially improved by strict adherence to good hygienic practices (GHP) and manufacturing (GMP) throughout the food chain and the constant monitoring of critical control points (CCP) (Mihaiu et al., 2011). Therefore, in 
this paper we aimed to evaluate compositional and microbiological parameters for certain types of meat products obtained in a small scale unit.

\section{MATERIALS AND METHODS}

To assess the quality of meat products obtained in a butchery type unit in Maramures County, the following categories of samples were taken, divided in batches, from January-May 2014, 15 samples from the following product categories: fresh products, semismoked salami, raw sausage smoked and dried, raw smoked specialties. In order to obtain accurate results from each product category samples were taken from five different batches, and from each batch of products 3 samples were collected. All the samples were taken in compliance with the legislation regulations. (Ordin 13/2005; ISO 18593/2004). After collection, the samples were transported in isotherm bags at $4^{\circ}$ $6^{\circ} \mathrm{C}$ temperature, to the DSVSA laboratory from Cluj Napoca, where they were subjected to immediate processing. Compositional parameters: protein, fat and humidity content were determined by the automated method using the FoodScan apparatus and for determining the nitrites and $\mathrm{NaCl}$ standard methods were used. To assess the degree of contamination for meat products, the following standard microbiological methods were used: identification of Salmonella spp. (SR EN ISO 6579/ AC/2006), identification of Escherichia coli beta glucuronidase-positive (SR ISO 16649-2/2007). The results were statistical and mathematical analyzed using the Origin 8.5 program, using the single factor categorical analysis system ANOVA.

\section{RESULTS AND DISCUSSIONS}

Assessment of compositional and microbiological parameters for the category of semi-smoked salami.

From the results obtained it was found that the average value of the proteins in the semismoked salami samples are within the limits 11.3 \pm 0.42 and $14.2 \pm 0.32 \mathrm{~g} \%, 6.6 \%$ of all samples examined do not fall within the minimum limits set by the legislation, in accordance to the quality characteristics of the product (fig. 1). Our results were different from the ones obtained by Krotz et al. (2008) obtained in a study on protein / nitrogen determination in meat and meat products, for semi-smoked salami obtaining values between $27.51 \pm 0.12$ and $28.52 \pm 0.32 \mathrm{~g} \%$.
The results regarding the fat parameter were between $22.4 \pm 1.26$ and $28.3 \pm 2.32 \mathrm{~g} \%, 13.3 \%$, did do not fall within the limits of this parameter and in accordance with the quality characteristics of this product (fig. 2)

The results also showed that the humidity values for semi-smoked salami samples ranged between $48.77 \pm 5.6 \mathrm{~g} \%$ and $51.9 \pm 2.32 \mathrm{~g} \%$, all values being within the appropriate limits of this parameter according to the quality characteristics of this product.

Nitrites values ranged between $3.15 \pm 0.32$ and $1289 \pm 0.12 \mathrm{mg} / \mathrm{kg}$ and the $\mathrm{NaCl}$ values were between $1.95 \pm 0.32$ and $2.4 \pm 0.12 \mathrm{~g} \%$, all the results being within the maximum limits. The results obtainde by Bara (2009), in the research study regarding the quality of meat products, were close to our values, ranging between $1.51 \pm 0.31$ and $2.60 \pm 0.28 \mathrm{~g} \%$. From a microbiological point of view, all semi-smoked salami products were negative for bacteria belonging to Salmonella and Escherichia genera.

Assessment of compositional and microbiological parameters for raw-smoked sausage.

In the case of sausages samples, protein mean values ranged between $11.2 \pm 2.22$ and $18.2 \pm 1.42$ g\%. $13.33 \%$ of the analyzed samples fall within the limits for this parameter in accordance with the quality characteristics of the product (fig. 3). Following the results of the study for determining protein/nitrogen in meat and meat products, made by Krotz et al. (2008), they obtained an average value of $10.9 \pm 0.15 \mathrm{~g} \%$, all samples beeing below the limit corresponding to this parameter.

From the analysis of the results regarding fat determination in raw-smoked sausage, the values were within $17.24 \pm 0.16$ and $22.9 \pm 3.22$, beeing in the limits for this parameter, in accordance with the quality characteristics of this product (fig. 4).

Regarding the humidity parameter, the results were found between 53.59 $\pm 2.6-57.19 \pm 5.5 \mathrm{~g} \%$, $33 \%$ of all samples examined fall outside the limits for this parameter.

The statistical analysis of the results found that nitrites ranged between $1.62 \pm 0.32$ and $8.68 \pm 0.12 \mathrm{mg} \%$, all samples falling within the maximum limits ( $\max 10 \mathrm{mg} / 100 \mathrm{~g}$ ). Similar results were reported by Zlateva et Nikolova (2011), in a study on nitrate levels in sausages in Bulgaria, which revealed values between the limits 0.31 and $1.86 \mathrm{mg} / 100 \mathrm{~g}$. $\mathrm{NaCl}$ values ranged 
between $1.75 \pm 0.72$ and $2.64 \pm 0.32 \mathrm{~g} \%$, all samples falling within the maximum allowed ( $3 \mathrm{~g} \%)$. The results of Kovačević et al. (2011) in a study on the possibilities to reduce the amount of salt in traditional "Slavonian" sausage, the values ranged between 2.69 and $3.85 \mathrm{~g} \%$ in accordace with the quality characteristics of this product.

As in the case of the samples of semi-smoked salami, also in the case of smoked salami no Salmonella and Escherichia genus bacteria were detected.

Assessment of compositional and microbiological parameters for your raw-dried smoked ham

From the results obtained it was found that the average protein ranged between $17.3 \pm 1.26$ $24.09 \pm 2.21 \mathrm{~g} \%, 53.33 \%$ of all samples being various ( $\min 22 \%$ ), considering the quality characteristics of this product (fig. 5). Higher values of proteins were obtained by Janes et al. (2012) in a study regarding the determination of protein in „Kraški pršut” ham (29.5 $\pm 1.2 \mathrm{~g} \%)$, all samples falling within the limits for this parameter.

At the determination of humidity in the specialties samples, the values were between $39.15 \pm 4.4$ and $45.6 \pm 5.5 \mathrm{~g} \%, 6.6 \%$ of samples fall outside the limit, in accordance with the quality characteristics of this product (fig. 6).

Regarding the nitrites value in all samples, only in lots 4 and 5 positive samples were identified, the values were between $0.98 \pm 0.12$ and $1.62 \pm 0.32$, all samples falling within the maximum limits (max. 10\%). Similar results were obtained by Krotz et al. (2008) on the level of nitrites and nitrates in meat products which obtaining values between 1.16 and $1.5 \mathrm{mg} \%$, unlike the $\mathrm{NaCl}$ results obtained in the semi-smoked salami and sausages samples $(\mathrm{p}<0.05)$, where the specialties values were significantly higher, being $3.11 \pm 0.54$ and between $7.2 \pm 0.82$, all samples falling within the appropriate parameter (max 9\%).

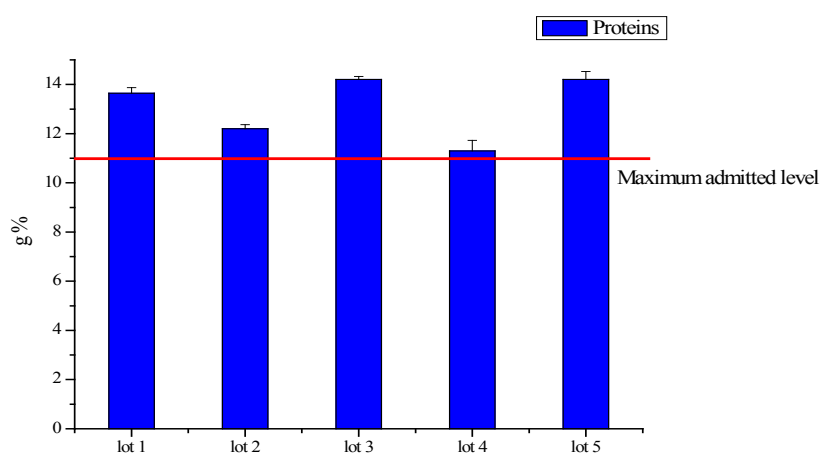

Fig. 1. Protein average values in semismoked salami.

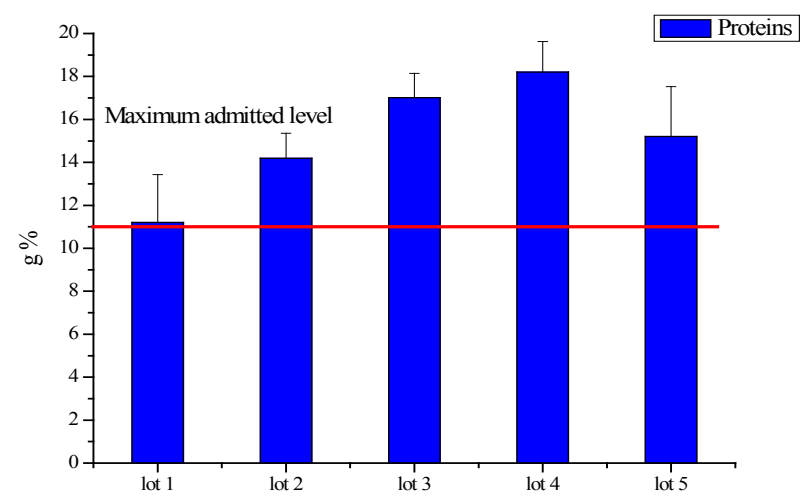

Fig. 3. Protein average values in raw smoked sausages.

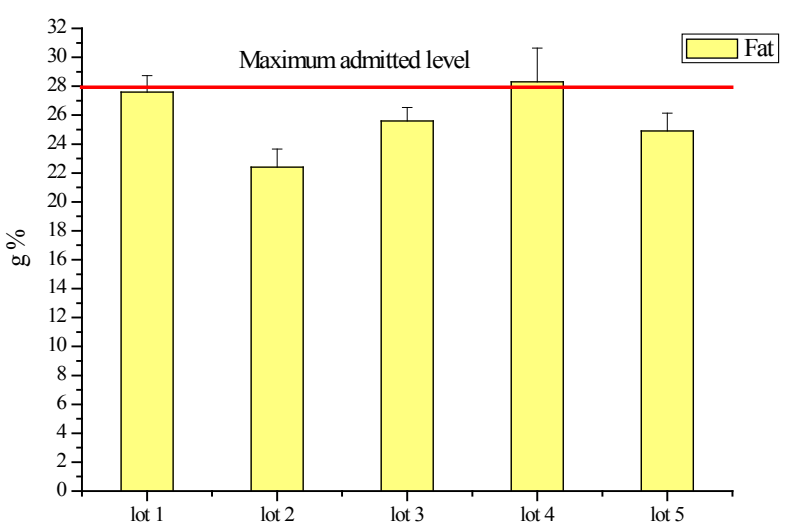

Fig. 2. Fat average values in semismoked salami

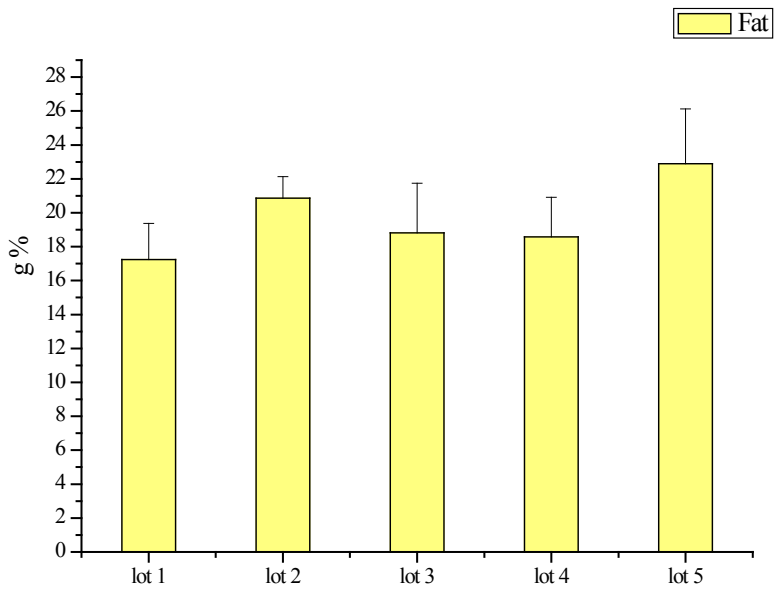

Fig. 4. Fat average values in raw smoked sausages. 


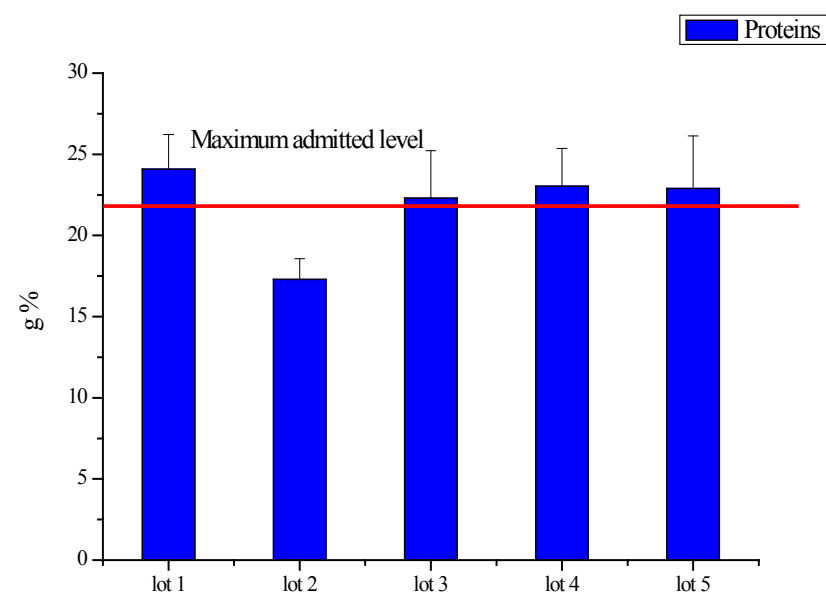

Fig. 5. Protein average values in raw smoked ham.

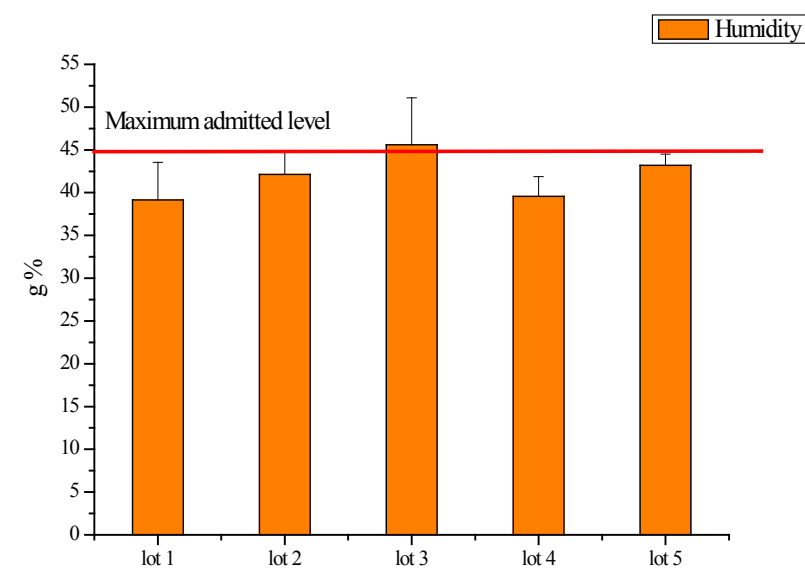

Fig. 6. Humidity average values in raw smoked ham.

In the samples of raw-dried smoked specialties, Salmonella or Escherichia germs were not identified, which shows the responsibility of the processor. Similar results on the presence of pathogens from Salmonella and Escherichia genus have been reported by Kovačević et al., 2011.

\section{CONCLUSION}

Non compliences for compositional parameters in semi-smoked salami category were identified in terms of total protein or fat. The nonconformities identified for raw-smoked sausages were the low protein and exceedings in fat and humidity values. Dry raw smoked specialties present non-conformities in some parameters represented by low protein and high humidity for whose values exceed the maximum limits. The microbiological risk parameters $E$. coli and Salmonella is low in all meat products, which shows that the unit under study has accomplished the criteria of hygiene and safety along the whole technological flow of meat processing.

\section{REFERENCES}

1. Apostu S, Stănescu V (2010). Igiena, inspecția şi siguranța alimentelor de origine animală, Volum I, Editura Risoprint Cluj-Napoca.

2. Apostu S, Stănescu V (2010). Igiena, inspecția şi siguranța alimentelor de origine animală, Volum 2, Editura Risoprint Cluj-Napoca.

3. Banu C (2009). Tratat de industrie alimentară Tehnologii alimentare, Volumul 2, Editura ASAB Bucureşti.

4. Bara L (2009). Research regarding the quality checking of the meat products from demismaked group, Analele Universității din Oradea, Fascicula: Ecotoxicologie, Zootehnie şi Tehnologii de Industrie Alimentară, pp. 99104.

5. Bărzoi D, Apostu S (2002). Microbiologia produselor alimentare, Editura Risoprint Cluj-Napoca.

6. Janeš L, Bolta ŠV, Škrlep M, Čandek-Potokar M, Prevolnik M (2012). Determination of free amino acid content in the Slovenian dry-cured ham Kraški pršut and product characterization, Acta Agriculturae Slovenica, 100(1): 29-35.

7. Kovačević D, Suman K, Lenart L, Frece J, Mastanjević K, Šubarić D (2011). Salt reduction in Homemade Slavonian Sausage: effect on compositional, physico-chemical, colour and texture parameters, sensory characteristics and hygienic quality, XIII (4): 270-274.

8. Krotz L, Ciceri E, Giazzi G (2008). Nitrogen/Protein determination in meat derivative products using the Thermo Scientific FLASH 4000, Italy.

9. Mihaiu M., S. D. Dan, Jecan C, Tăbăran A (2011). Controlul sănătății cărnii şi produselor din carne, Editura Risoprint Cluj-Napoca.

10. Mihaiu M., S. D. Dan, Jecan C, Tăbăran A (2014). Inspecția şi controlul alimentelor, Editura Risoprint Cluj-Napoca.

11. Zlateva D, Nikolova M (2011). Determination of nitrite content in sausages offered on the bulgarian market, Denka, Forum ware international 2: 25-34.

12. *** Ordin nr. 560 din 16 august 2006, pentru aprobarea normelor $\mathrm{cu}$ privire la comercializarea produselor din carne, emis de Ministerul Agriculturii, Padurilor şi Dezvoltării Rurale, publicat in Monitorul Oficial nr. 10 din 8 ianuare 2007.

13. *** Ordin nr. 13 din 24 ianuarie 2005 (*actualizat*), privind aprobarea Normei sanitare veterinare şi pentru siguranța alimentelor ce stabileşte regulile pentru prelevare de probe de produse de origine animală pentru examenul de laborator (actualizat până la data de 04.04. 2015*).

14. ${ }^{* * *}$ Regulamentul (CE) nr. 1441, (2007), de modificare a Regulamentului (CE) nr. 2073/2005 privind criteriile microbiologice pentru produsele alimentare. 
15. *** ISO 18593, (2004). Specifies horizontal methods for sampling techniques using contact plates or swabs on surfaces in the food industry environment (and food processing plants), with a view of detecting or enumerating viable microorganisms.
16. *** SR EN ISO 6579 AC/2009, Metoda orizontală pentru detectarea bacteriilor din genul Salmonella.

17. *** SR EN ISO 16649-2,(2007), Metoda orizontală pentru numărarea Escherichia coli pozitivă la $\beta$-glucuronidază. 